\title{
ASYMPTOTIC EXPANSIONS AND COMPARISON OF BIVARIATE PARAMETER MEANS
}

\author{
NEVEN ELEZOVIĆ AND LENKA VUKŠIĆ
}

\begin{abstract}
The subject of this paper is the analysis of bivariate parameter means: general power mean, generalized logarithmic mean, Gini mean and Stolarsky mean. Asymptotical analysis of these means are made and series of corresponding coefficients are calculated. Using these information, a necessary conditions for the comparison of these means are derived. This approach enables better understanding of relations between these means.
\end{abstract}

Mathematics subject classification (2010): 26D15, 41A60.

Keywords and phrases: Asymptotic expansion; bivariate parameter means.

\section{REFERENCES}

[1] H. Alzer, S. Ruscheweyh, On the intersection of two-parameter mean value families, Proc. Amer. Math. Soc., 1299 (2001), 2655-2662.

[2] P. S. Bullen, Handbook of Means and Their Inequalities, Kluwer Academic Publishers, 2003.

[3] P. S. Bullen, D. S. Mitrinović, P. M. Vasić, Means and theirs inequalities, D Reidel, Dordrecht, 1988.

[4] Chao-Ping Chen, Asymptotic representations for Stolarsky, Gini and the generalized Muirhead means, JIPAM 114.

[5] Chao-Ping Chen, Neven Elezović And Lenka Vukšić, Asymptotic formulae associated with the Wallis power function and digamma function, Journal of Classical Analysis 2, 2 (2013), 151-166.

[6] P. CZINDER, Zs. PÁLES, Local monotonicity properties of two-variable Gini means and the comparison theorem revisited, J. Math. Anal. Appl. no. 301 (2005) 427-438.

[7] P. CZINDER, Zs. PÁles, Some comparison inequalities for Gini and Stolarsky means, Math. Inequal. Appl. vol. 9 no. 4 (2006) 607-616.

[8] N. Elezović, Asymptotic inequalities and comparison of classical means, J. Math. Inequal. (to appear).

[9] N. Elezović, C. Giordano and J. PeČarić, The best bounds in Gautschi's inequalities, Math. Inequal. Appl., 3 (2000), 239-252.

[10] N. Elezović And J. PeČArić, Differential and integral $f$-means and applications to digamma function, Math. Inequal. Appl. 3 (2000), 189-196.

[11] N. Elezović AND L. VUKŠIĆ, Asymptotic expansions of bivariate classical means and related inequalities, J. Math. Inequal. 8, 4 (2014), 707-724.

[12] N. ElezoviĆ AND L. VUKŠIĆ, Asymptotic expansions of integral means and applications to the ratio of gamma functions, Appl. Math. Comput. (2014), http://dx.doi.org/ $10.1016 / \mathrm{j}$. amc.2014.02.026

[13] A. ERdÉlYi, Asymptotic expansions, Dover Publications, 1956.

[14] H. W. Gould, Coefficient identities for powers of Taylor and Dirichlet series, The American Mathematical Monthly, 81, 1 (1974) 3-14.

[15] H. W. Gould, M. E. Mays, Series expansions of means, J. Math. Anal. Appl. 101 (1984), 611-621.

[16] E. B. Leach, M. C. Sholander, Extended mean values, The American Mathematical Monthly, 85, 2 (1978) 84-90.

[17] E. B. Leach, M. C. Sholander, Extended mean values II, J. Math. Anal. Appl. 92 (1983) 207-223. 
[18] D. S. Mitrinović, J. E. PeČArić, A. M. Fink, Classical and New Inequalities in Analysis, D Reidel, Dordrecht, 1993.

[19] E. Neuman, Zs. PÁles, On comparison of Stolarsky and Gini means, J. Math. Anal. Appl. 278 (2003) 274-284.

[20] E. Neuman, J. Sandor, Inequalities involving Stolarsky and Gini means, Mathematica Pannonica 14/1 (2003) 29-44.

[21] Zs. PÁLEs, Inequalities for differences of powers, J. Math. Anal. Appl. 131 (1988) 271-281.

[22] Zs. PÁLES, Inequalities for sums of powers, J. Math. Anal. Appl. 131 (1988) 265-270.

[23] K. B. Stolars Ky, Generalizations of the Logarithmic Mean, Mathematics Magazine 48, 2 (1975), 87-92.

[24] K. B. Stolarsky, The power and generalized logarithmic means, Amer. Math. Monthly 87, 7 (1980), 545-548. 